\title{
PENERAPAN SIX SIGMA UNTUK PENANGANAN PENGENDALIAN KUALITAS PRODUK
}

\author{
Eko Nursubiyantoro dan Darmawan Agus Setiawan \\ Program studi Teknik Industri, Jurusan Teknik Industri \\ Fakultas Teknik Industri \\ Universitas Pembangunan Nasional"Veteran" Yogyakarta \\ Jl. Babarsari 2, Tambakbayan, Yogyakarta 55281 \\ Telp/Fax (0274) 486258 \\ email: industri_fti@upnyk.ac.id
}

\begin{abstract}
ABSTRAK
Kualitas lampu pijar secara umum ditentukan dari parameter terangnya lampu, bentuk bola lampu, dan bentuk filament yang berpijar saat lampu menyala. Jika lampu pijar pada tahap jauh dari ketiga kriteria tersebut maka lampu dikatakan tidak berkulitas dan dinyatakan reject. Penelitian dilakukan pada mesin exhaust departemen produksi lampu pijar PT GE Lighting Indonesia, data yang digunakan adalah jumlah produk jadi dan produk cacat di mesin exhaust, serta Faktor-faktor yang menyebabkan terjadinya kecacatan. Pengolahan data dilakukan dengan cara menghitung tingkat dan peluang kecacatan, menghitung DPMO, membuat paretto diagram, dan Fishbone diagram. Nilai sigma dari mesin exhaust berada pada kisaran 4,6 $\sigma$, nilai ini cukup bagus untuk proses produksi namun perlu ditingkatkan melalui perbaikan-perbaikan lain secara terusmenerus. Kecacatan paling banyak dijumpai pada mesin exhaust adalah patah poli dengan prosentase 69,8\%. Faktor utama penyebab kecacatan adalah setting mesin yang kurang tepat dan bagian poli sendiri rapuh karena suhu pembakaran dari proses sebelumnya kurang tepat.
\end{abstract}

Kata Kunci: Kualitas, kecacatan dan perbaikan.

\section{PENDAHULUAN}

Konsep meminimasi ongkos operasi dan memaksimalkan kapasitas dan laju produksi menjadi fokus penting dalam menjalankan proses kegiatan bisnis. Peningkatan sekecil apapun dalam sebuah operasi akan dapat mengurangi ongkos produksi atau meningkatkan output. Kualitas lampu pijar (Incandescent Lamp) secara umum ditentukan dari parameter terangnya lampu, bentuk bola lampu, dan bentuk filament yang berpijar saat lampu menyala. Jika lampu pijar pada tahap jauh dari ketiga kriteria tersebut maka lampu dikatakan tidak berkulitas dan dinyatakan reject. Setiap proses pengolahan yang dilakukan secara manual maupun mekanis, tidak dapat menghasilkan produk yang sempurna, penyimpangan akan terjadi walaupun dalam skala kecil. Meminimalisasi cacat (defect) pada tiap operasi akan dapat mengurangi ongkos produksi dan waktu proses produksi yang terbuang karena memproses part yang tidak memenuhi standar.

\section{LANDASAN TEORI}

Pengendalian merupakan salah satu bagian dari manajemen, dilakukan dengan tujuanagar yang direncanakan dapat dilaksanakan dengan baik sehingga mencapai target dan tujuan yang ingin dicapai. Pengertian pengendalian menurut pandangan beberapa ahli adalah sebagai berikut: Pengendalian adalah usaha untuk mencapai tujuan tertentu melalui perilaku yang diharapkan (Mulyadi, 2007), pengendalian merupakan tahap penentu keberhasilan manajemen (Indra Bastian, 2006), pengendalian adalah suatu tindakan pengawasan yang disertai tindakan pelurusan/korektif (Randy R Wrihatnolo dan Riant Nugroho Dwijowijoto, 2006). Pengendalian adalah suatu proses penjaminan dimana perusahaan dan orang-orang yang 
berada dalam perusahaan tersebut dapat mencapai tujuan yang telah ditetapkan. Jadi pengendalian merupakan tindakan yang dilakukan untuk menjamin tercapainya tujuan dengan cara mengadakan pengawasan yang ditindaklanjuti koreksi terhadap proses yang sedang berlangsung sehingga sesuai dengan yang diinginkan / standar yang telah ditetapkan. Dengan adanya pengendalian diharapkan dapat mengurangi terjadinya penyimpangan-peyimpangan dan dapat mengarah pada tujuan utama.

\section{Pengertian Dasar dari Kualitas}

Definisi dari kualitas biasanya menggambarkan karakteristik langsung dari suatu produk seperti: kinerja (performance), keandalan (reliability), kemudahan dalam penggunaan (ease of use), dan sebagainya. Dalam Quality Vocabulary, kualitas didefinisikan sebagai totalitas dari karakteristik suatu produk yang menunjang kemampuannya untuk memuaskan kebutuhan yang dispesifikasikan atau ditetapkan. Kualitas seringkali diartikan sebagai kepuasan pelanggan (customer satisfaction) atau kesesuaian terhadap kebutuhan atau persyaratan (conformance to the requirement). Pada dasarnya pengendalian kualitas (Quality Management) didefinisikan sebagai suatu cara meningkatkan kinerja secara terus-menerus pada setiap level operasi atau proses, dalam setiap area fungsional dari suatu perusahaan, menggunakan sumber daya manusia dan modal yang tersedia. Montgomery (1996) mendefinisikan pengendalian kualitas adalah aktivitas teknik dan manajemen yang digunakan untuk mengukur ciri-ciri kualitas produk, membandingkan dengan spesifikasi atau persyaratan dan mengambil tindakan apabila ada perbedaan antara penampilan yang sebenarnya dengan standar. Assauri (1998) mendefiniskan pengendalian kualitas adalah merencanakan dan melaksanakan cara yang paling ekonomis untuk membuat sebuah barang yang akan bermanfaat dan memuaskan tuntutan konsumen secara maksimal. Handoko (2001) mendefinikan pengendalian kualitas merupakan upaya mengurangi kerugiankerugian akibat produk rusak dan banyaknya sisa produk atau scrap.

\section{Six Sigma}

Six Sigma tersusun dari dua kata yaitu: six yang berarti enam dan sigma yang merupakan symbol dari standar deviasi atau dapat pula diartikan sebagai ukuran satuan statistik yang menggambarkan kemampuan suatu proses dan ukuran nilai sigma dinyatakan dalam DPU (Defetc Per Unit) atau PPM (Part Per Million). Proses dengan nilai sigma yang lebih tinggi (pada suatu proses) akan mempunyai defect yang lebih sedikit (baik jumlah maupun jenisnya). Semakin bertambah nilai sigma, makan semakin berkurang Quality Cost dan Cycle Time. Six Sigma merupakan sebuah metodologi terstruktur untuk memperbaiki suatu proses dengan memfokuskan pada usaha-usaha untuk memperkecil variasi yang terjadi (process variance) sekaligus mengurangi cacat suatu produk yang keluar dari spesifikasi dengan menggunakan metode statistic dan tools quality lainnya. Tujuan Six Sigma adalah memperbaiki sistem manajemen suatu perusahaan atau instansi lain yang terkait dengan pelanggan, memperbaiki proses produksi yang berfokus mengurangi kecacatan produk sehingga dapat mencapai 3,4 DPMO (Pande et al., 2000). Prinsip Six Sigma adalah sebagai manajemen kualitas didasari oleh tiga prinsip dasar yaitu fokus pada pelanggan, partisipasi dan kerjasama semua individu yang terkait, dan perbaikan serta pembelajaran secara terus menerus. Program peningkatan kualitas Six Sigma harus melibatkan manajemen dari tingkat atas sampai tingkat bawah secara intensif. Program peningkatan kualitas Six Sigma dapat dilaksanakan dengan metode DMAIC (define, measure, analyze, improvement, control). DMAIC dalam program peningkatan kualitas Six Sigma merupakan suatu siklus sistematis. Siklus tersebut dapat dilakukan untuk berbagai macam permasalahan, dari yang sederhana hingga masalah yang komplek, untuk produk barang maupun jasa. Tujuan dari siklus 
DMAIC ini adalah untuk melangkah dari menemukan permasalahan, mengidentifikasi penyebab masalah, hingga akhirnya menemukan solusi untuk memperbaiki.

Beberapa istilah yang menjadi dasar dalam memahami konsep pengendalian kualitas dengan Six Sigma. Critical to Quality (CTQ) mengacu pada apa yang pelanggan anggap penting dalam setiap proses. CTQ diperoleh dari observasi pelanggan (voice of customer) yang digabungkan dengan analisa bisnis (critical business requirement). Defect tingkat kecacatan produk yang keluar dari standar yang telah ditetapkan. Defect per Unit (DPU) tingkat kecacatan dihitung per unit, jenis pengukuran ini cenderung fokus pada produk akhir. Defect per Opportunity (DPO). Ukuran kegagalan yang dihitung dalam peningkatan kualitas Six Sigma, yang menunjukkan banyaknya cacat atau kegagalan per satu kesempatan. Formula DPO adalah banyaknya cacat atau kegagalan yang ditemukan, dibagi dengan banyaknya unit yang diperiksa dikalikan banyaknya CTQ potensial yang menyebabkan cacat tersebut.

$D P O=($ total produk cacat $) /($ total produksi $\mathrm{X}$ CTQ) Defect per Million Opportunities
$(D P M O)$. Ukuran kegagalan dalam program peningkatan kualitas Sig Sixma yang menunjukkan kegagalan per sejuta kesempatan.

Formula DPMO adalah sebagai berikut

$D P M O=($ total produk cacat $) /($ total produksi $\mathrm{x}$ $C T Q) \times 1.000 .000$ atau

$D P M O=D P O \times 1.000 .000$

Define, Measure, Analyze, Improve, Control $(D, M, A, I, C)$ merupakan proses untuk peningkatan terus menerus menuju target Six Sigma. DMAIC dilakukan secara sistemik, berdasarkan ilmu pengetahuan dan fakta.

\section{METODOLOGI}

Penelitian ini dilakukan pada mesin exhaust departemen produksi lampu pijar PT GE Lighting Indonesia dengan produk diteliti adalah lampu pijar 75 Watt dengan merk GE. Data yang digunakan adalah jumlah produk jadi dan produk cacat di mesin exhaust, serta Faktor-faktor yang menyebabkan terjadinya kecacatan. Pengolahan data dilakukan dengan cara menghitung tingkat dan peluang kecacatan, menghitung DPMO, membuat paretto diagram, dan Fishbone diagram.

\section{PENGOLAHAN DATA DAN ANALISIS}

Data produksi dan jumlah cacat dari departemen produksi adalah sebagai berikut:

Tabel 1. Data jumlah produksi dan jumlah cacat.

\begin{tabular}{|c|c|c|}
\hline Tanggal & $\begin{array}{c}\text { Jumlah } \\
\text { Produksi }\end{array}$ & $\begin{array}{c}\text { Jumlah } \\
\text { Cacat }\end{array}$ \\
\hline 1 & 23461 & 73 \\
2 & 22650 & 113 \\
3 & 22509 & 86 \\
4 & 0 & 0 \\
5 & 0 & 0 \\
6 & 21037 & 113 \\
7 & 21256 & 77 \\
8 & 19479 & 84 \\
9 & 21109 & 182 \\
10 & 0 & 0 \\
\hline
\end{tabular}

\begin{tabular}{|c|c|c|}
\hline Tanggal & $\begin{array}{c}\text { Jumlah } \\
\text { Produksi }\end{array}$ & $\begin{array}{c}\text { Jumlah } \\
\text { Cacat }\end{array}$ \\
\hline 11 & 0 & 0 \\
12 & 0 & 0 \\
13 & 21617 & 108 \\
14 & 19110 & 108 \\
15 & 22740 & 232 \\
16 & 22112 & 157 \\
17 & 20767 & 225 \\
18 & 21568 & 231 \\
19 & 0 & 0 \\
20 & 20838 & 194 \\
\hline
\end{tabular}

\begin{tabular}{|c|c|c|}
\hline Tanggal & $\begin{array}{c}\text { Jumlah } \\
\text { Produksi }\end{array}$ & $\begin{array}{c}\text { Jumlah } \\
\text { Cacat }\end{array}$ \\
\hline 21 & 23297 & 174 \\
22 & 22970 & 135 \\
23 & 22374 & 109 \\
24 & 19608 & 122 \\
25 & 22909 & 156 \\
26 & 0 & 0 \\
27 & 31361 & 296 \\
28 & 34022 & 177 \\
29 & 35012 & 169 \\
& & \\
\hline
\end{tabular}

Total jumlah produksi $=511.806$

Total jumlah cacat $=3.321$ 
Tabel 2. Data penyebaran jumlah cacat

\begin{tabular}{|c|c|c|c|c|c|c|c|c|c|c|c|c|c|c|c|c|c|c|c|c|c|c|c|c|c|c|c|c|c|}
\hline Jenis Cacat & 1 & 2 & 3 & 4 & 5 & 6 & 7 & 8 & 9 & 10 & 11 & 12 & 13 & 14 & 15 & 16 & 17 & 18 & 19 & 20 & 21 & 22 & 23 & 24 & 25 & 26 & 27 & 28 & 29 \\
\hline$A$ & & & & & & & & & & & & & & 1 & & & & & & & & & & & & & & & \\
\hline$B$ & 9 & 17 & 21 & & & 22 & 24 & 25 & 19 & & & & 19 & 24 & 28 & 18 & 17 & 33 & & 18 & 18 & 23 & 27 & 20 & 20 & & 44 & 40 & 33 \\
\hline$C$ & & & & & & & & & & & & & & & & & & 1 & & & & & & & 2 & & & & 1 \\
\hline$D$ & & & & & & & & & & & & & & & & & & & & & & & & & & & & & \\
\hline$E$ & 38 & 81 & 51 & & & 88 & 34 & 49 & 139 & & & & 69 & 76 & 150 & 132 & 198 & 163 & & 146 & 81 & 96 & 58 & 86 & 128 & & 240 & 114 & 102 \\
\hline$F$ & & & & & & & 2 & & & & & & & & & & & & & & & 1 & & & & & & & 3 \\
\hline$G$ & & 8 & 6 & & & 3 & 17 & 10 & 24 & & & & 20 & 7 & 5 & 7 & & 15 & & 17 & 13 & 9 & 18 & 16 & 6 & & 12 & 19 & 29 \\
\hline$H$ & 26 & 7 & 8 & & & & & & & & & & & & 3 & & 6 & & & 13 & 62 & 6 & 6 & & & & & 4 & 1 \\
\hline$A$ & & & & & & & & & & & & & & & 46 & & 4 & 19 & & & & & & & & & & & \\
\hline
\end{tabular}

\section{Keterangan:}

$A \quad$ : Pecah gelas pada Cetak

$B$ : Pecah gelas pada bodi

$C$ : Meledak dalam Oven

$D$ : Getter Barium warnanya putih

$E$ : Patah poli

$F \quad$ : Meletus pada saat Tipping

$G$ : Patah Tiping Off

$H \quad$ : Tiping off terlalu panjang 


\section{Tingkat Kecacatan dan Peluang Kecacatan}

Tingkat kecacatan dihitung menggunakan $C T Q$ penyebab kecacatan, berdasarkan Tabel 2 maka:

Tingkat kecacatan $=\frac{\text { total } \text { cacat }}{\text { total } \text { produksi }}=\frac{3.321}{511.806}$

$$
=0,00649
$$

Peluang cacat $=\frac{\text { tingkat kecacatan }}{C T Q}=\frac{0,00649}{9}$

$$
=7,2 \times 10^{4}
$$

\section{Nilai Sigma}

Nilai sigma dapat diperoleh melalui langkahlangkah sebagai berikut:

Menghitung $D P O$

$$
D P O=\frac{\text { total cacat }}{\text { total produksi } X C T Q}
$$

Menghitung $D P M O$

$D P M O=\frac{\text { total produk cacat }}{\text { total produksi } X \text { CTQ }} \times 1.000 .000$ atau

$D P M O=D P O \times 1.000 .000$

\section{Konversi nilai DPMO ke Sigma}

Mengkonversikan nilai DPMO ke Sigma, dapat dilakukan dengan dua cara, pertama dapat menggunakan tabel konversi DPMO ke Sigma dan yang kedua menggunakan Microsoft Excel dengan formula sebagai berikut: $\quad=$ NORMSINV $((1000000$ DPMO)/1000000)+1.5

Hasil perhitungan nilai $D P M O$ dan nilai

\begin{tabular}{|c|c|c|c|c|c|c|}
\hline & $\begin{array}{c}\text { Total } \\
\text { Produksi }\end{array}$ & $\begin{array}{l}\text { Total } \\
\text { Cacat }\end{array}$ & CTQ & DPO & DPMO & Sigma \\
\hline 1 & 23461 & 73 & 9 & 0,000345727 & 345,72 & 4,89 \\
\hline 2 & 22650 & 113 & 9 & 0,000554329 & 554,32 & 4,76 \\
\hline 3 & 22509 & 86 & 9 & 0,000424522 & 424,52 & 4,83 \\
\hline 4 & 0 & 0 & 9 & 0 & 0 & 0 \\
\hline 5 & 0 & 0 & 9 & 0 & 0 & 0 \\
\hline 6 & 21037 & 113 & 9 & 0,000596832 & 596,83 & 4,74 \\
\hline 7 & 21256 & 77 & 9 & 0,000402501 & 402,50 & 4,85 \\
\hline 8 & 19479 & 84 & 9 & 0,000479148 & 479,14 & 4,80 \\
\hline 9 & 21109 & 182 & 9 & 0,000957991 & 957,99 & 4,6 \\
\hline 10 & 0 & 0 & 9 & 0 & 0 & 0 \\
\hline 11 & 0 & 0 & 9 & 0 & 0 & 0 \\
\hline 12 & 0 & 0 & 9 & 0 & 0 & 0 \\
\hline 13 & 21617 & 108 & 9 & 0,000555119 & 555,11 & 4,76 \\
\hline 14 & 19110 & 108 & 9 & 0,000627943 & 627,94 & 4,72 \\
\hline 15 & 22740 & 232 & 9 & 0,001133587 & 1133,58 & 4,55 \\
\hline 16 & 22112 & 157 & 9 & 0,000788913 & 788,91 & 4,65 \\
\hline 17 & 20767 & 225 & 9 & 0,001203833 & 1203,83 & 4,53 \\
\hline 18 & 21568 & 231 & 9 & 0,001190035 & 1190,03 & 4,53 \\
\hline 19 & 0 & 0 & 9 & 0 & 0 & 0 \\
\hline 20 & 20838 & 194 & 9 & 0,001034435 & 1034,43 & 4,58 \\
\hline 21 & 23297 & 174 & 9 & 0,000829864 & 829,86 & 4,64 \\
\hline 22 & 22970 & 135 & 9 & 0,000653026 & 653,02 & 4,71 \\
\hline 23 & 22374 & 109 & 9 & 0,000541303 & 541,30 & 4,76 \\
\hline 24 & 19608 & 122 & 9 & 0,000691328 & 691,32 & 4,69 \\
\hline 25 & 22909 & 156 & 9 & 0,000756617 & 756,61 & 4,67 \\
\hline 26 & 0 & 0 & 9 & 0 & 0 & 0 \\
\hline 27 & 31361 & 296 & 9 & 0,001048719 & 1048,71 & 4,57 \\
\hline 28 & 34022 & 177 & 9 & 0,000578057 & 578,05 & 4,74 \\
\hline 29 & 35012 & 169 & 9 & 0,000536324 & 536,32 & 4,77 \\
\hline
\end{tabular}
Sigma, disajikan pada Tabel 3 berikut ini.

Tabel 3. Hasil Perhitungan DPMO dan Konversi ke Nilai Sigma 


\section{Diagram Pareto}

Berdasarkan Tabel 2 tentang kecacatan produk, dibuat diagram pareto untuk mengidentifikasi jenis kecacatan paling dominan sebagai acuan untuk mengevaluasi langkah-langkah yang akan diambil dalam perbaikan proses.

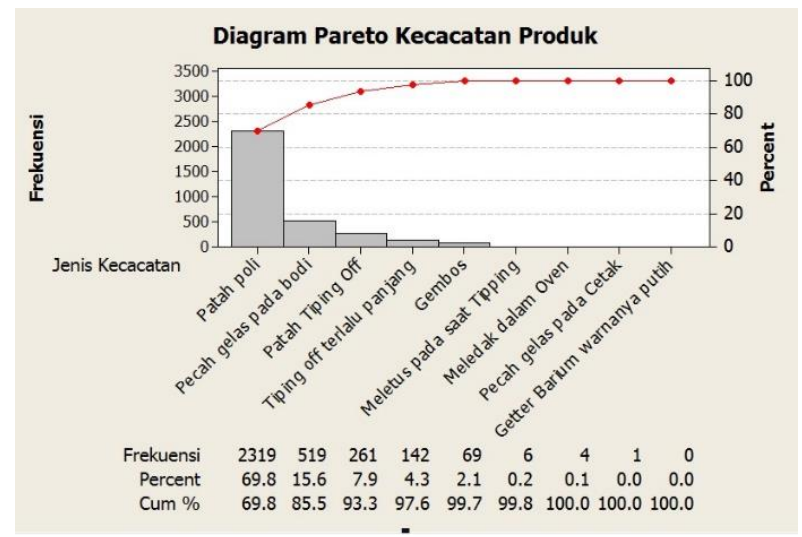

Gambar 1. Diagram Pareto Kecacatan Produk

\section{Diagram Sebab Akibat}

Berdasarkan Gambar 1 jenis kecacatan paling dominan adalah patah poli, penyebab patah poli digambarkan dalam diagram fishbone sebagai berikut:

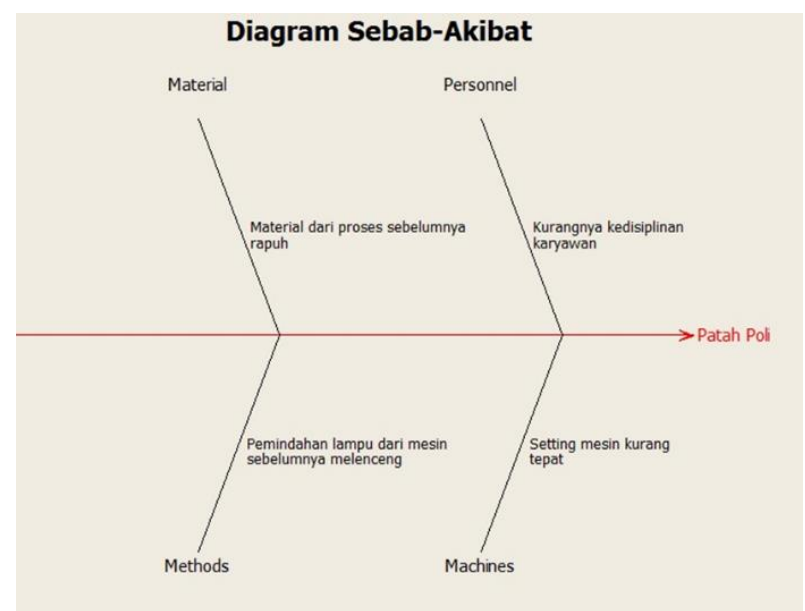

Gambar 2. Diagram fishbone Kecacatan Produk

\section{Analisis}

Berdasarkan Gambar 1 diketahui bahwa kecacatan paling dominan pada mesin exhaust berasal dari patah poli dengan presentase sebesar 69,8\%. Hasil observasi dengan mekanik yang menangani line 1 , penyebab terbesar dari patah poli adalah setting mesin yang kurang tepat. Saat lampu dipindahkan dari mesin sealing ke mesin exhaust, penyangga ujung poli di mesin exhaust sedikit melenceng. Akibatnya saat mesin exhaust bergerak, ujung poli akan bersenggolan dengan bagian lain dari mesin exhaust kemudian patah. Berdasarkan Gambar 2 jenis kecacatan kritis yang harus segera ditangani yaitu patah poli. Sebab-sebab dari patah poli diuraikan secara spesifik sebagai berikut:

Faktor manusia, kedisplinan karyawan terkait pemakaian mesin yang terus menerus saat waktunya maintenance karena kendala target produksi. Ketelitian operator yang berbeda, sehingga terkadang lampu cacat dari proses sebelumnya lolos uji ke mesin exhaust. Faktor metode pemindahan lampu dari mesin sebelumnya melenceng, perpindahan lampu dari mesin sealing ke mesin exhaust, sedikit kasar. Faktor mesin Setting mesin kurang tepat, tidak tepatnya posisi penyangga poli dimesin exhaust menyebabkan poli patah. Faktor bahan baku material dari proses sebelumnya rapuh, pemanasan yang kurang merata dari proses sebelumnya menyebabkan poli mudah patah.

Setelah penyebab kecacatan dominan dan faktor-faktornya diidentifikasi, dilakukan perbaikan setiap faktor untuk mengurangi peluang terjadinya patah poli. Tindakan tersebut antara lain: Faktor manusia peningkatan pengawasan pada karyawan, pendidikan dan pelatihan kerja secara berkala mengenai pengoperasian dan perawatan mesin, meningkatkan fasilitas kenyaman di tempat kerja untuk mengurangi kelelahan. Faktor metode mendesain ulang cara pemindahan lampu dari mesin sealing ke mesin exhaust. Faktor mesin melakukan setting mesin secara berkala dengan cermat. Faktor bahan baku men-setting ulang suhu pembakaran bagian poli dari mesin flare sampai mesin sealing, 
tidak meloloskan bahan baku yang di luar standar yang telah ditetapkan.

\section{KESIMPULAN DAN SARAN}

Kesimpulan dari penelitian ini adalah nilai sigma dari mesin exhaust berada pada kisaran 4,6 $\sigma$, nilai ini cukup bagus untuk proses produksi namun perlu ditingkatkan melalui perbaikan-perbaikan lain secara terusmenerus. Kecacatan paling banyak dijumpai pada mesin exhaust adalah patah poli dengan prosentase $69,8 \%$. Faktor utama penyebab kecacatan adalah setting mesin yang kurang tepat dan bagian poli sendiri rapuh karena suhu pembakaran dari proses sebelumnya kurang tepat.

Saran bagi penelitian selanjutnya adalah melibatkan kecacatan pada proses-proses produksi lainnya sehingga dapat dilakukan perbaikan-perbaikan yang lebih baik.

\section{DAFTAR PUSTAKA}

Assauri, S., 1998. Manajemen Produksi dan Operasi, Fakultas Ekonomi Universitas Indonesia, Jakarta.

Gaspersz, V.,2002, Pedoman Implementasi Program Six Sigma, PT. Gramedia Pustaka Utama, Jakarta.
Gaspers, V. 2001, Total Quality Management, PT. Gramedia Pustaka Utama, Jakarta.

Handoko, T.H. 2001.,Manajemen Personalia dan Sumber Daya Manusia, BPFE Yogyakarta.

Montgomery, D. C. (1996). Introduction to Statistical Quality Control (6th ed). John New York: Wiley and Sons Inc.

Mulyadi. 2007. Sistem Perencanaan dan Pengendalian Manajemen. Salemba. Empat. Jakarta

Pande, P.S, Robert P.N., Roland R.C. 2002, The Six Sigma Way : bagaimana GE, Motorola dan PerusahaanTerkenal Lainnya Mengasah Kinerja Mereka, Andi, Yogyakarta.

Siswanto, 2007, Operation Research. Jilid 2. Erlangga, Jakarta

Walpole, R.E., Myers, R.H., Myers, S.L., \&Ye, K .(2012). Probability \& Statistics for Engineers \& Scientists (9th ed.). United States of America: Person Education Inc.

Wrihatnolo, R.R., dan Dwijowijoto, R.N., 2006, Manajemen pembangunan Indonesia : sebuah pengantar dan panduan, Elex Media Komputindo, Jakarta. 